\title{
Evaluation of flocculated concentrates from intensive shrimp pond water as a substitute for microalgal concentrates in the nursery culture of juvenile oyster (Crassostrea belcheri)
}

\author{
Suwat Tanyaros $\cdot$ Woraporn Tarangkoon $\cdot$ Tossaporn Klomkleing
}

Received: 30 July 2015/Accepted: 28 March 2016/Published online: 28 April 2016

(C) The Author(s) 2016. This article is published with open access at Springerlink.com

\begin{abstract}
Intensive shrimp pond water typically contains high densities of microalgae and may have a great potential as a substitute for microalgae in the nursery culture of juvenile oysters as this stage needs large amount of microalgae. Two experiments with different phytoplankton composition in flocculated concentrates from shrimp pond water were investigated to compare the effect on preservation and use of flocculated concentrates from intensive shrimp pond as a partial substitute for microalgae concentrates for the nursery culture of juvenile oysters (Crassostrea belcheri) was evaluated. The results show that total crude protein content in flocculated concentrates mostly contain unidentified nanocyanobacteria preserved in refrigerator at $4{ }^{\circ} \mathrm{C}$ gradually decreased from the first week in experiment 1 , while a slight decrease in crude protein content appeared after the third week in flocculated concentrates dominated by the Bacillariophyceae and unidentified nanocyanobacteria groups in experiment 2 . The pheophytin $a$ :chlorophyll $a$ ratio suddenly increased during the third week of storage and most of the fatty acid composition was absent after four weeks of storage in both experiments. Substituting $75 \%$ of microalgal concentrates in feed with flocculated concentrates from shrimp pond water showed no significant differences in growth performance in experiment 1 , but higher growth performance in experiment 2 in comparison with control treatment (100\% microalgal concentrates). Our findings indicate that a partial substitution of flocculated concentrates of up to $75 \%$ from shrimp pond water for microalgal concentrates would lead to better growth in juvenile oysters.
\end{abstract}

Keywords Flocculated concentrates · Intensive shrimp pond · Daily growth rate · Crassostrea belcheri

\section{Introduction}

Highly nutritional microalgae are normally used to feed the larval and adult stages of bivalves in hatcheries. However, microalgae production requires a high level of investment and is very costly. Production of live microalgae has been seen as a major hatchery operating costs, accounting for 20-50\% of the total bivalve seed production costs (Coutteau and Sorgeloos 1992). Hatchery-reared oysters in the nursery with a low mortality rate in the sea should be bigger than $5 \mathrm{~mm}$ in length (Tanyaros and Tarangkoon 2014), but feeding

S. Tanyaros $(\varangle) \cdot$ W. Tarangkoon

Faculty of Science and Fisheries Technology, Rajamangala University of Technology Srivijaya, Trang 92150, Thailand

e-mail: stanyaros@gmail.com

T. Klomkleing

Aquaculture Technology Program, Faculty of Science and Fisheries Technology, Rajamangala University of Technology Srivijaya, Trang 92150, Thailand 
of spat from post settling up to this size result in high consumption of microalgae. It is at this stage of culturing that an alternative food source is most needed. Today, this problem can be solved using preserved microalgae which can be produced by concentrating algae from mass culture and preserving the products through refrigeration, freezing or drying (McCausland et al. 1999; Ponis et al. 2008). Initial cost estimates for supplement feed showed that it will add 2-3\% to juvenile oyster production costs during the nursery phase when oysters are 0.5-3 mm in size (McCausland et al. 1999). Successful partial replacement for a diet of live microalgae has been reported in several studies using microalgal concentrates (Nell and O'Connor 1991; McCausland et al. 1999; Heasman et al. 2000; Robert et al. 2001; Brown and Robert 2002; Ponis et al. 2003a, b, 2008; Knuckey et al. 2006).

Shrimp waste and uneaten feed are released directly into the water and settle at the bottom of the pond. Subsequently, the decomposition of wastes can produce excess inorganic nutrients which stimulate the production of algae in the ponds (Funge-Smith and Briggs 1998). Microalgal communities in intensive shrimp ponds have been studied (Tookwinas and Songsangjinda 1999; Yusoff et al. 2002; Rodriguez and Paez-Osuna 2003; Islam et al. 2004; Casé et al. 2008; Shaari et al. 2011) and Bacillariophyceae constituted the largest number of species and accounted for the high densities in those reports. Bacillariophyceae often represents the main food source in marine ecosystems (Zhukova and Aizdaicher 1995) and many species have been used as food in oyster hatchery operation as summarized by Brown et al. (1989). As shrimp pond water typically contains elevated densities of microalgae, integrated culture of shrimp and oysters has been attempted to reduce microalgal densities in shrimp culture units (Sandifer and Hopkins 1996; Jones and Preston 1999; Tanyaros 2000; Jones et al. 2001; Tanyaros et al. 2002). Manzi et al. (1988) and Jacob et al. (1993) showed the potential of Crassostrea virginica biculture using marine shrimp pond water as feed. High growth and survival rates for both shrimp and oysters were obtained in their studies. The results of these studies suggest the idea of harvesting microalgae from shrimp pond water in concentrates form may have potential for substituting microalgae in the nursing of juvenile oyster in a hatchery. In the past, flocculation of microalgae in marine shrimp culture system for improving the water quality has been investigated (Lertsutthiwong et al. 2009). However, the potential of flocculated concentrates from intensive shrimp pond water as a substitute for microalgae in the rearing of oysters has not been previously investigated. This article describes the preservation and use of flocculated concentrates from intensive shrimp pond in the hatchery diet for the nursery culture of the juvenile oyster, $C$. belcheri.

\section{Materials and methods}

Preparation of flocculated concentrates from shrimp pond water

Water color is an important indicator of bio-optical properties as well as the general composition of microalgae. Types of microalgae which give the water a yellow-green or yellow-brown color are good for shrimp culture ponds. This color of water indicates a high probability that the water contains Bacillariophyceae (Reynolds 2006). Therefore, shrimp pond water of this desirable color from the shrimp farm at the Faculty of Science and Fisheries Technology, Rajamangala University of Technology Srivijaya, Trang campus, southern Thailand was selected and pumped into a $500 \mathrm{~L}$ fiberglass tank by submersible pump. The suspended materials in the pond water were flocculated by the method of Brown and Robert (2002). NaOH was added to the point of maximal mixing of the pond water to increase the $\mathrm{pH}$ of the water to between 10.0 and 10.6, then a white precipitate formed. At this stage, the polyelectrolyte [Polyacrylamide solution (SigmaAldrich)] was added to give a final concentration of $0.5 \mathrm{mg} \mathrm{L}^{-1}$. When large flocs formed $(\sim 1 \mathrm{~min})$, the mixing was stopped and the flocs were allowed to settle under gravity force (10-20 min). Surface water was then siphoned off and the floc collected. The suspension was deflocculated immediately by adjusting the $\mathrm{pH}$ of the floc slurry to $\mathrm{pH} 7.5-8.0$ using concentrated $\mathrm{HCl}$. The floc slurry was allowed to settle overnight at $4{ }^{\circ} \mathrm{C}$ and any supernatant was removed. The flocculated material was kept in a refrigerator at $4{ }^{\circ} \mathrm{C}$ prior to use in experiments. For each shrimp pond flocculation, three replicates of floc sample $(20 \mathrm{~mL})$ were collected and kept in a plastic bottle and then the samples were fixed in $10 \%$ formaldehyde. The density of microalgae in the flocculated concentrates was determined using a compound microscope (Olympus CH2, Tokyo, Japan). The number of cells was calculated and cell densities expressed as the number of cells per milliliter. The 
nutrient concentrations in intensive shrimp pond increased with the cultured period and enhanced nutrient input affected phytoplankton density and composition (Casé et al. 2008). Therefore, two experiments with different of phytoplankton composition in flocculated concentrates from shrimp pond water were investigated to compare the effects on preservation and growth performance in juvenile oyster after substitute for microalgal concentrates. This study shows that unidentified nanocyanobacteria $(99.2 \%)$ constituted the greatest bulk of the microalgae population in the flocculated concentrates from shrimp pond water in experiment 1, while Bacillariophyceae $(66.4 \%)$ and unidentified nanocyanobacteria $(33.3 \%)$ were the dominant groups in experiment 2 (Table 1).

Microalgal cultures

A stock of microalgae (Chaetoceros calcitrans and Tetraselmis suecica) was grown in 1 L Erlenmeyer flasks (2 L Erlenmeyer flask) and then transferred to a 5 L Carboy using the Conwy medium (Walne 1974). Cultures were grown under continuous illumination by cool white fluorescent lights. Mass culture of microalgae was performed in $500 \mathrm{~L}$ open fiberglass tanks under ideal sunlight conditions. When the late logarithmic growth phase was reached, the microalgae were harvested by flocculation described by Brown and Robert (2002). Microalgal concentrates were preserved in a refrigerator at $4{ }^{\circ} \mathrm{C}$ prior been used in experiments.

Flocculated concentrates preservation experiment

To study the effect of preservation on nutritional composition, three replicates of $500 \mathrm{~mL}$ of flocculated concentrates from shrimp pond water samples were collected and kept in plastic bottles. The samples were preserved in a refrigerator at $4{ }^{\circ} \mathrm{C}$ for 4 weeks. During preservation, $50 \mathrm{~mL}$ samples were taken weekly from each bottle for analysis of crude protein by the Kjeldahl method according to the Association of Official Analytical Chemists (2012). To analyze the pigment ratio for each preservation period, $10 \mathrm{~mL}$ of floc samples were taken and poured into $100 \mathrm{~mL}$ of filtered sea water. The samples were disaggregated to single cell suspensions by shaking prior to use for pigment determination. Chlorophyll $a$ and pheophytin $a$ concentration were determined using the spectrophotometric method (Lorenzen 1967), where the absorption of the extract was measured before and after acidification at 750 and $665 \mathrm{~nm}$ Chlorophyll $a$ and pheophytin $a\left(\mu \mathrm{g} \mathrm{mL}^{-1}\right)$ were given by the following formulae of Lorenzen (1967):

$$
\begin{gathered}
\text { Chlorophylla }\left(\mathrm{mg} \mathrm{L}^{-1}\right)=\left[26.7 v\left(A_{665 \mathrm{na}}-A_{665 \mathrm{a}}\right)\right] /(V l) \\
\text { Pheophytin } a\left(\mathrm{mg} \mathrm{L}^{-1}\right)=\left[26.7 v\left(1.7 A_{665 \mathrm{a}}-A_{665 \mathrm{na}}\right)\right] /(V l)
\end{gathered}
$$

\begin{tabular}{|c|c|c|c|c|}
\hline \multirow[t]{2}{*}{ Group } & \multicolumn{2}{|l|}{ Experiment $1(n=4)$} & \multicolumn{2}{|l|}{ Experiment $2(n=3)$} \\
\hline & Density (cell $\mathrm{mL}^{-1}$ ) & $\%$ & Density (cell $\mathrm{mL}^{-1}$ ) & $\%$ \\
\hline Bacillariophyceae & $\begin{array}{l}2.19 \times 10^{5} \pm 3.73 \times 10^{5} \\
\text { Nitzschia spp. }(0.79) \\
\text { Others }(0.01)\end{array}$ & 0.8 & $\begin{array}{l}2.64 \times 10^{7} \pm 4.71 \times 10^{7} \\
\text { Chaetoceros spp. }(66.39) \\
\text { Others }(0.01)\end{array}$ & 66.4 \\
\hline Dinophyceae & & & $\begin{array}{l}1.20 \times 10^{5} \pm 8.67 \times 10^{4} \\
\text { Protoperidinium spp. }(0.29) \\
\text { Others }(0.01)\end{array}$ & 0.3 \\
\hline Cyanophyceae & $\begin{array}{l}2.61 \times 10^{7} \pm 1.57 \times 10^{7} \\
\text { Unidentified nanocyanobacteria }\end{array}$ & 99.2 & $\begin{array}{l}1.33 \times 10^{7} \pm 1.09 \times 10^{7} \\
\text { Unidentified nanocyanobacteria }\end{array}$ & 33.3 \\
\hline Total & & 100 & & 100 \\
\hline
\end{tabular}

Table 1 Dominant group of phytoplankton in selected shrimp pond water 
where $v$ is the volume of $90 \%$ acetone $(\mathrm{mL}) ; V$ is the volume of the filtered sample $(\mathrm{mL}) ; A_{665 \mathrm{na}}$ is the absorbance at $665 \mathrm{~nm}$ before acidification; $A_{665 \mathrm{a}}$ is the absorbance at $665 \mathrm{~nm}$ after acidification; and $l$ is the path length of the cuvette $(\mathrm{cm})$.

At the beginning and at the fourth week of the experiments, flocculated concentrates samples were taken to determine fatty acid composition. The samples were extracted with chloroform-methanol (Folch et al. 1957) and portions of the total lipid extract were taken to determine fatty acid compositions. Fatty acids within the lipid extracts were derivatized to fatty acid methyl esters (FAME) using $14 \%$ boron trifluoride-methanol (Van Wijngaarden 1967) before analysis of fatty acid composition by gas chromatography (model $6890 \mathrm{~N}$; GC-FID, Agilent Technologies, Wilmington, NC, USA) using helium as the carrier gas and a flame ionization detector.

Substitution of flocculated concentrates for microalgae in rearing juvenile oysters

\section{Experimental diets and juvenile oysters}

A mixed microalgal concentrates consisting of 50/50\% C. calcitrans and T. suecica was replaced by flocculated concentrates at different ratios $(0 \%$ (control), 25, 50, 75 and $100 \%)$. The daily use of microalgal concentrates for both species in control (100\% microalgal concentrates) was calculated by the method of Helm et al. (2004). The volume for each species of microalgal concentrate was measured by cylinder and added to $10 \mathrm{~L}$ of filtered seawater. The suspension was thoroughly mixed by mildly agitation and then the percentage of transmission (\%T) of the microalgal suspension was measured by spectrophotometer (biochrom Libra S11, Cambridge, England) and the value was recorded. In substitution treatments, the volume of microalgae concentrates were decreased according to the substitution rate, while the volume of flocculated concentrates from shrimp pond water was added to make the percentage of transmission similar in value to that of the control prior to use for the experiment.

Juvenile $C$. belcheri were produced in the hatchery of the Marine Shellfish Breeding Research Unit of the Faculty of Science and Fisheries Technology in Rajamangala University of Technology Srivijaya, Trang Campus, Thailand. The animals were graded by size to prevent growth retardation. Mean $( \pm$ SD) shell widths (dorso-ventral) of $2.43 \pm 0.15$ and $1.86 \pm 0.003 \mathrm{~mm}$, shell lengths (antero-posterior) of $2.23 \pm 0.09$ and $1.82 \pm 0.003 \mathrm{~mm}$ and individual wet weights of 2.78 and $1.50 \mathrm{mg}$ were used in experiments 1 and 2, respectively.

\section{Experimental system and procedures}

A semi-closed recirculation system was designed for nursing hatchery-reared juvenile oysters (see Fig. 1). Four sets were used, each consisting of a submersible pump, a rectangular $105 \mathrm{~L}(50 \times 70 \times 30 \mathrm{~cm})$ fiberglass tank for placement of the nursing units, a cylindrical plastic $30 \mathrm{~L}$ container $(60 \mathrm{~cm}$ diameter and $25 \mathrm{~cm}$ depth) for food storage, and three sets of cylindrical PVC pipe $(15.2 \mathrm{~cm}$ diameter $\times 12 \mathrm{~cm} \mathrm{depth})$ used as nursing units. Each cylindrical PVC pipe was drilled $10 \mathrm{~cm}$ from the bottom for a $1.86 \mathrm{~cm}$ diameter overflow pipe. A screen using $600 \mu \mathrm{m}$ mesh was fixed by a PVC clamp to the bottom of each cylindrical PVC section. The volume of water in each nursing unit was $1.82 \mathrm{~L}$ during system operation. Each nursing unit had a capacity of 754 juvenile oysters, equal to a stocking density of 4 juveniles $\mathrm{cm}^{-2}$ (Tanyaros et al. 2012). The water flow in each nursing unit was controlled by an adjustable valve at the overflow pipe to maintain a flow rate of $4 \mathrm{~L} \mathrm{~min}{ }^{-1}$ (Tanyaros et al. 2012). The experiment was set up using a completely randomized design (CRD), and each treatment was conducted in triplicate.

The water was totally renewed every 2 days, and food was added twice a day (morning and evening) at a rate calculated by the method mentioned above. The feeding rate for each nursing unit was adjusted weekly according to the wet weight of the oysters obtained each week. The number of surviving animals was ascertained at the end of the experiment. Samples from each replicate were taken weekly for measurement of shell width, shell length and wet weight. The daily growth rate (DGR) was then calculated using the method of Pérez Camacho et al. (1998). At the end of the experiment, all juvenile oysters from each experimental unit were counted. The survival rate was calculated and expressed as percentages. 

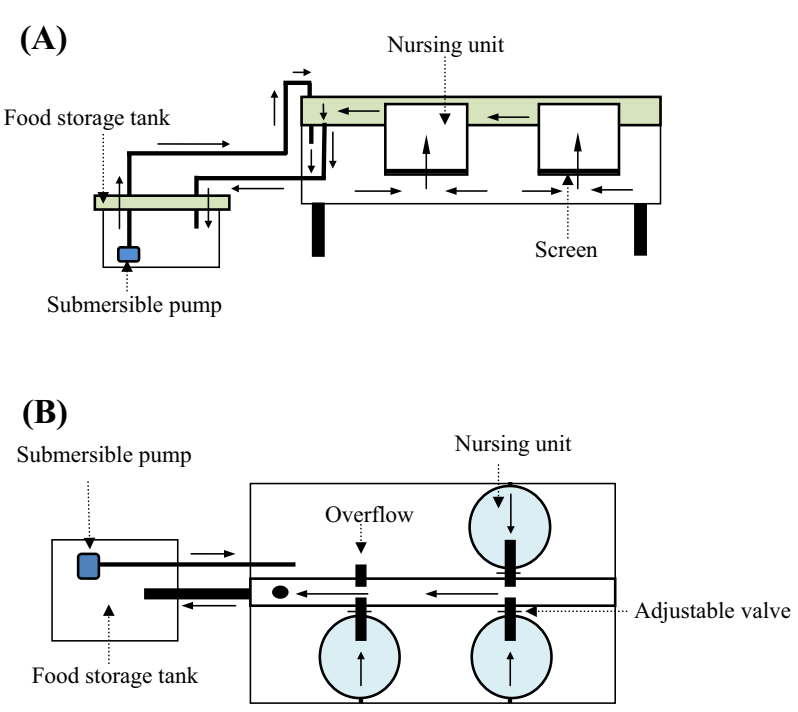

Fig. 1 Diagram showing the experimental system: a side view and $\mathbf{b}$ top view

Water salinity ranged from 31.6 to 33.2 and 29.7 to 30.3 ppt over the study period in experiments 1 and 2 , respectively. Water quality parameters were as follows: dissolved oxygen $\geq 5.97 \mathrm{mg} \mathrm{L}^{-1}$, total ammonia nitrogen $\leq 0.047 \mathrm{mg} \mathrm{L}^{-1}$, water temperature $25.8-28.1{ }^{\circ} \mathrm{C}$ and $\mathrm{pH} \geq 7.88$ in experiment 1 and dissolved oxygen $\geq 6.68 \mathrm{mg} \mathrm{L}^{-1}$, total ammonia nitrogen $\leq 0.53 \mathrm{mg} \mathrm{L}^{-1}$, water temperature $29.7-31.6{ }^{\circ} \mathrm{C}$ and $\mathrm{pH}$ $\geq 7.92$ in experiment 2 .

Statistical analysis

Data were analyzed statistically using one-way ANOVA to determine differences among treatments. If significant effects were present, the data were then subjected to Tukey's test to identify significant differences among treatment means.

\section{Results}

Experiment 1

\section{Flocculated concentrates preservation}

Crude protein content in flocculated concentrates preserved in a refrigerator at $4{ }^{\circ} \mathrm{C}$ gradually decreased from the first week. The pheophytin $a$ :chlorophyll $a$ ratio suddenly increased during the third week of storage (Fig. 3). After 4 weeks of storage, most of the fatty acid composition in flocculated concentrates had completely degraded (Table 2 ).

\section{Effect of flocculated concentrates from shrimp pond water supplementation}

The juvenile oysters were nursed in a semi-closed recirculation system for four weeks. There were significant differences $(P<0.05)$ in their mean absolute shell length and width. Substitution of $75 \%$ of flocculated concentrates for microalgae concentrates in feed showed non-significant differences in both experiments in absolute shell growth compared with substitution of 25 and $50 \%$ of flocculated concentrates or $100 \%$ microalgal concentrates. Substitution with $100 \%$ flocculated concentrates resulted in the lowest absolute shell growth (Fig. 4a). Mean absolute shell widths were $0.075 \pm 0.01,0.079 \pm 0.02,0.50 \pm 0.01,0.30 \pm 0.01$ and $0.019 \pm 0.01 \mathrm{~mm} \mathrm{day}^{-1}$ and mean absolute shell lengths were $0.037 \pm 0.002 \%, \quad 0.040 \pm 0.02$, 
Table 2 Fatty acid (FA) composition of fresh microalgae and flocculated concentrates from shrimp pond water at the outset (W0) and at the fourth week (W4) of storage at $4{ }^{\circ} \mathrm{C}$

\begin{tabular}{|c|c|c|c|c|}
\hline \multicolumn{5}{|c|}{ Fatty acid content $(\mathrm{mg} / 100 \mathrm{~g})$} \\
\hline \multirow{2}{*}{$\frac{\text { Fatty acid compositions }}{\text { Monosaturate FA }}$} & \multicolumn{2}{|c|}{ Experiment 1} & \multicolumn{2}{|c|}{ Experiment 2} \\
\hline & 406.9 & 769.6 & 63.1 & ND \\
\hline \multicolumn{5}{|l|}{ Polyunsaturate FA } \\
\hline C18:2n6 & 27.2 & 63.5 & 8.3 & ND \\
\hline C18:3n6 & 52.5 & ND & ND & ND \\
\hline C18:3n3 & 6.3 & ND & 3.8 & ND \\
\hline C20:4n6 & 3.3 & ND & ND & ND \\
\hline C20:5n3 (EPA) & ND & ND & 8.9 & ND \\
\hline C22:6n3 (DHA) & 5.0 & ND & 9.6 & ND \\
\hline
\end{tabular}

$N D$ non detected

Table 3 Effect of partial replacement of microalgae with flocculated concentrates from shrimp pond water on the daily growth rate at the second $\left(\mathrm{DGR}^{2}\right)$ and at the fourth week $\left(\mathrm{DGR}^{4}\right)$ of the juvenile oyster C. belcheri

\begin{tabular}{|c|c|c|c|c|c|c|c|c|}
\hline \multirow[t]{2}{*}{ Substitution rate $(\%)$} & \multicolumn{4}{|l|}{ Experiment 1} & \multicolumn{4}{|l|}{ Experiment 2} \\
\hline & $\operatorname{DGR}^{2}\left(\%\right.$ day $\left.^{-1}\right)$ & $\%^{\mathrm{A}}$ & $\operatorname{DGR}^{4}\left(\%\right.$ day $\left.^{-1}\right)$ & $\%^{\mathrm{A}}$ & $\operatorname{DGR}^{2}\left(\%\right.$ day $\left.^{-1}\right)$ & $\%^{\mathrm{A}}$ & $\operatorname{DGR}^{4}\left(\%\right.$ day $\left.^{-1}\right)$ & $\%^{\mathrm{A}}$ \\
\hline 0 & $203.0 \pm 9.9$ & $100^{\mathrm{a}}$ & $236.7 \pm 5.7$ & $100^{\mathrm{ab}}$ & $35.1 \pm 4.1$ & $100^{\mathrm{c}}$ & $113.3 \pm 9.0$ & $100^{\mathrm{b}}$ \\
\hline 25 & $211.1 \pm 5.4$ & $104^{\mathrm{a}}$ & $251.2 \pm 9.0$ & $106^{\mathrm{a}}$ & $55.6 \pm 3.8$ & $160^{\mathrm{b}}$ & $183.1 \pm 13.8$ & $163^{\mathrm{a}}$ \\
\hline 50 & $213.0 \pm 1.6$ & $105^{\mathrm{a}}$ & $243.3 \pm 3.7$ & $102^{\mathrm{ab}}$ & $64.1 \pm 5.4$ & $183^{\mathrm{ab}}$ & $205.5 \pm 13.5$ & $181^{\mathrm{a}}$ \\
\hline 75 & $200.7 \pm 1.5$ & $99^{\mathrm{a}}$ & $228.5 \pm 5.1$ & $97^{\mathrm{b}}$ & $67.8 \pm 6.1$ & $195^{\mathrm{a}}$ & $203.8 \pm 4.3$ & $180^{\mathrm{a}}$ \\
\hline 100 & $184.8 \pm 2.1$ & $91^{\mathrm{b}}$ & $205.0 \pm 1.7$ & $87^{\mathrm{c}}$ & $28.9 \pm 1.3$ & $83^{\mathrm{c}}$ & $44.8 \pm 3.3$ & $40^{\mathrm{c}}$ \\
\hline
\end{tabular}

Different superscripts (vertical only) denote significant differences among means $(P<0.05)$

A DGR expressed as a percentage of DGR obtained with $100 \%$ microalgae

$0.033 \pm 0.004,0.017 \pm 0.004$ and $0.012 \pm 0.002 \mathrm{~mm} \mathrm{day}^{-1}$ for $0,25,50$ and $75 \%$ and $100 \%$ substitution with flocculated concentrates, respectively. Mean daily growth rate differed significantly among the treatments over the study period $(P<0.05)$. Substitution of flocculated concentrates for $75 \%$ of microalgae concentrates in feed resulted in no significant differences in daily growth rate in both the second and fourth week in comparison with 25 and $50 \%$ substitution with flocculated concentrates or $100 \%$ microalgal concentrates, while replacing $100 \%$ of microalgal concentrates with flocculated concentrates showed the lowest daily growth rate (Table 3). No differences among the mean percentages for survival at the end of the experiment $(P<0.05)$. Mean survival rates were $90.5 \pm 6.5,97.2 \pm 2.1,98.7 \pm 1.3,96.0 \pm 4.0$ and $94.4 \pm 4.7 \%$ for 0 , 25, 50, 75 and $100 \%$ substitution with flocculated concentrates, respectively (Fig. 5a).

\section{Experiment 2}

\section{Flocculated concentrates preservation}

A slight decrease in protein content appeared after the third week (Fig. 2). The pheophytin $a$ :chlorophyll $a$ ratio was increased at the third week of preservation (Fig. 3). Most of the fatty acid composition in flocculated concentrates had completely degraded after four weeks (Table 2).

\section{Effect of flocculated concentrates from shrimp pond water supplementation}

No differed on substitution of $75 \%$ of flocculated concentrates for microalgal concentrates in feed on growth performance compared with substitution of 25 and $50 \%$ of flocculated concentrates or $100 \%$ microalgal 


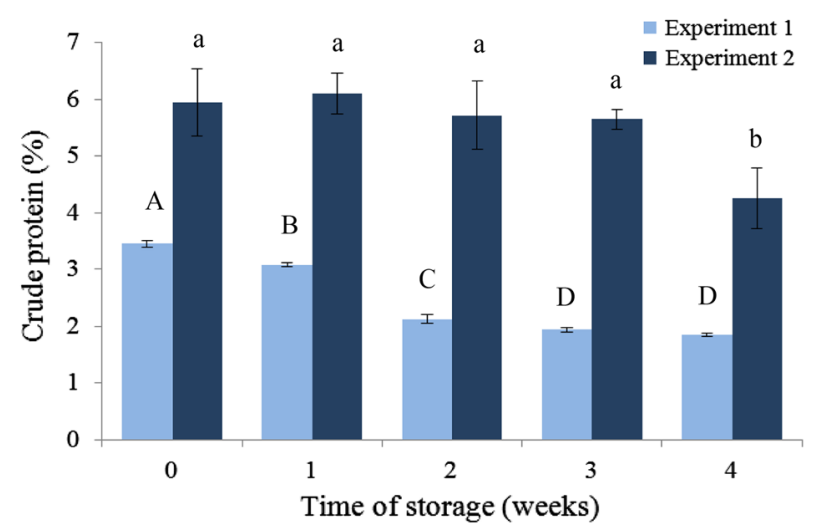

Fig. 2 Total protein content (average $\pm \mathrm{SD} ; n=3$ ) in flocculated concentrates from shrimp pond water during different weeks of storage at $4{ }^{\circ} \mathrm{C}$. Bars labeled with different letters are significantly different $(P<0.05)$

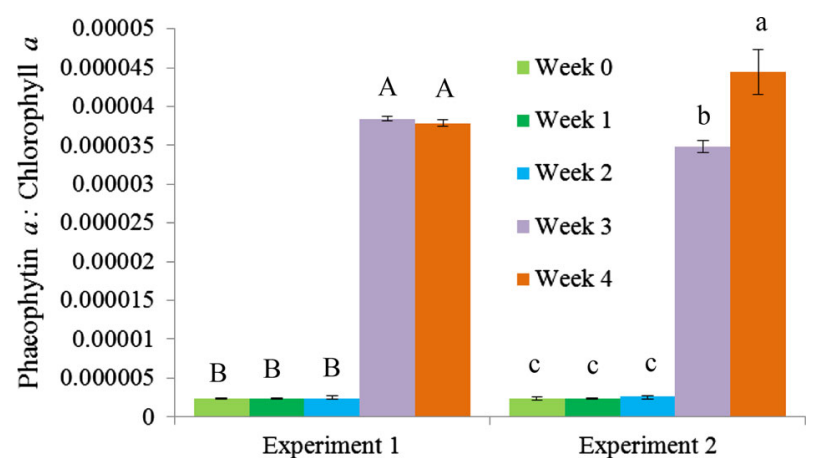

Fig. 3 Ratio of pheophytin $a$ :chlorophyll $a$ (average $\pm \mathrm{SD} ; n=3$ ) in flocculated concentrates from shrimp pond water during different weeks of storage at $4{ }^{\circ} \mathrm{C}$. Bars labeled with different letters are significantly different $(P<0.05)$

concentrates. Substitution with $100 \%$ flocculated concentrates resulted in the lowest absolute shell growth as same as in experiment 1 (Fig. 4b). Mean absolute shell widths were $0.077 \pm 0.003,0.105 \pm 0.01$, $0.135 \pm 0.01, \quad 0.113 \pm 0.02$ and $0.027 \pm 0.002 \mathrm{~mm} \mathrm{day}^{-1}$ and mean absolute shell lengths were $0.047 \pm 0.001,0.064 \pm 0.003,0.085 \pm 0.01,0.064 \pm 0.01$ and $0.015 \pm 0.003 \mathrm{~mm} \mathrm{day}^{-1}$ for $0,25,50$ and $75 \%$ and $100 \%$ substitution, respectively. Mean daily growth rate differed significantly among the treatments $(P<0.05)$. Replacing $75 \%$ of microalgae in feed with flocculated concentrates showed significant differences in survival rates in comparison with 25 and $50 \%$ replacement or $100 \%$ microalgal concentrates. Mean survival rates were $88.4 \pm 2.9,86.3 \pm 1.5,90.7 \pm 2.4,97.5 \pm 1.8$ and $91.8 \pm 1.9 \%$ for $0,25,50,75$ and $100 \%$ substitution with flocculated concentrates, respectively (Fig. 5b).

\section{Discussion}

Flocculated concentrates preservation

Flocculation is presented as a cost-effective alternative for preparing microalgal concentrates for the bivalve diet and is suited for on-site production (Knuckey et al. 2006). Flocculated concentrates from shrimp pond water contains a high concentration of microalgae, but the species compositions vary throughout the culture period. Changes in nitrogen-to-phosphorus ratios and ammonia concentrations coincided with changes in microalgal community structure (Burford 1997). Once the flocculated concentrate is obtained, suitable preservation is required to maintain nutritional value for a reasonable time. Previously, several methods have been used to preserve microalgal concentrates from on-site production, such as adding additives or preservatives (Tzovenis et al. 2004), freezing (Heasman et al. 2000) and refrigeration (Nunes et al. 2009). In 

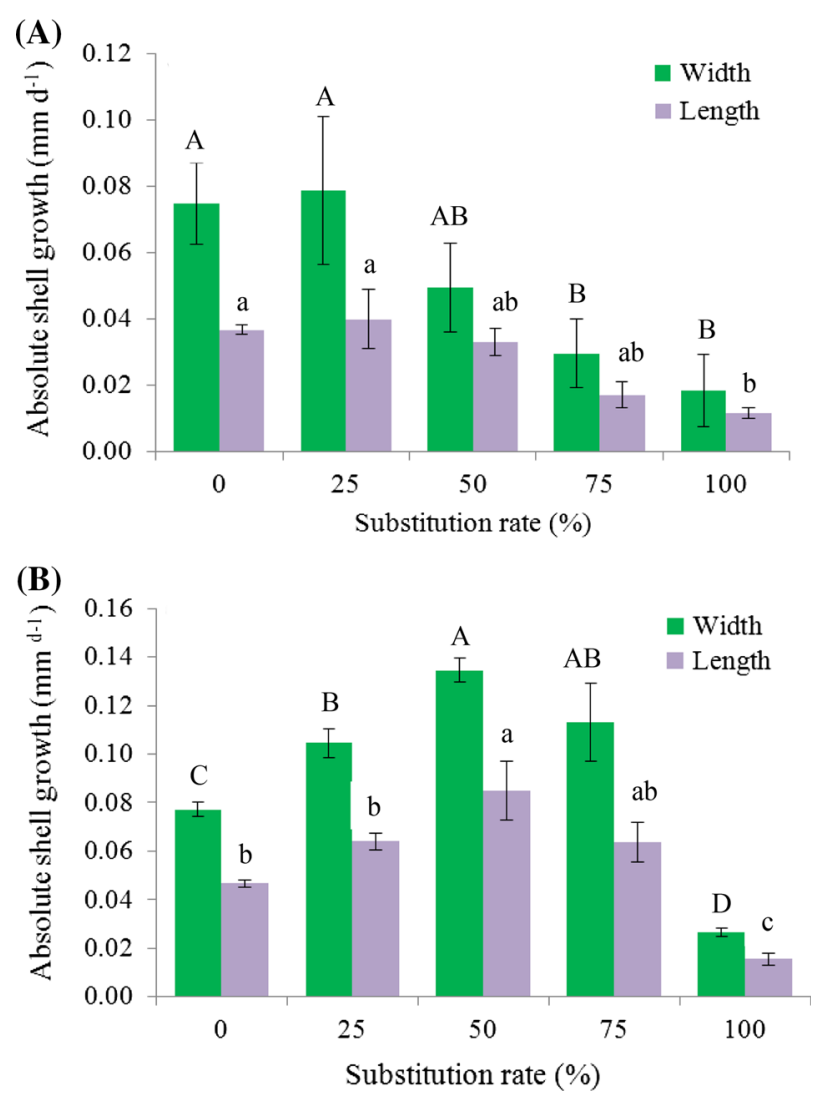

Fig. 4 Mean $( \pm S D)$ absolute shell length and width of hatchery-reared juvenile oysters fed on microalgae and algal concentrates from shrimp pond water at different ratios at the end of the 4 weeks experimental duration. Bars labeled with different letters are significantly different $(P<0.05)(\mathbf{A}=$ Experiment 1 and $\mathbf{B}=$ Experiment 2$)$

this study, the simple technique of storage in a refrigerator at $4{ }^{\circ} \mathrm{C}$ was selected as this method is easy and cost-effective for use in a hatchery. The results show the composition of microalgae in flocculated concentrates affected the nutritional value during the storage period. Flocculated concentrates containing unidentified nanocyanobacteria showed a reduction in crude protein content from the first week of storage, a very short shelf life. This is similar to findings in an experiment conducted by Brown and Robert (2002); there were dramatic decreases in protein content in microalgae concentrates during the first week of storage. However, the crude protein content in flocculated concentrates containing the groups Bacillariophyceae and unidentified nanocyanobacteria in this experiment decreased in the third week of storage. This finding is similar to that of a study involving concentrated $C$. calcitrans; the chemical composition of cells remained stable during the first 3 weeks of storage but the organic matter decreased significantly after that period (Ponis et al. 2003a). Generally, the maximum time the microalgal pastes can be kept and still retain its nutritional value equivalent to fresh microalgae ranged from about 1 to 4 weeks, depending upon the species of algae (Heasman et al. 2000). The pheophytin $a$ :chlorophyll $a$ ratio has been used as indicator of the chemical status of microalgal concentrates over the period of storage. In this study, the flocculated concentrates had greatly increased values in the pheophytin $a$ :chlorophyll $a$ ratio in the third week of the storage period in both experiments, as a consequence of deterioration of the stored cells. Several experiments have been investigated pheophytin $a$ :chlorophyll $a$ evolution in microalgal concentrates during the storage period (Brown and Robert 2002; Ponis et al. 2003a). Those results have shown variations in chlorophyll $a$ degradation, depending on species. For instance, for Pavlova lutheri, the value for pheophytin $a$ :chlorophyll $a$ increased remarkably during the second week of storage (Ponis et al. 2003a), while concentrates of Thalassiosira pseudonana showed no sign of degradation of chlorophyll $a$ after around 21 days storage at $4{ }^{\circ} \mathrm{C}$ (Knuckey et al. 2006). Furthermore, after a 1-month storage period, the algae concentrate of $C$. calcitrans forma pumilum, Chaetoceros sp., Skeletonema costatum obtained by flocculation showed a loss in chlorophyll $a$ of approximately 20-30\% (Brown and 

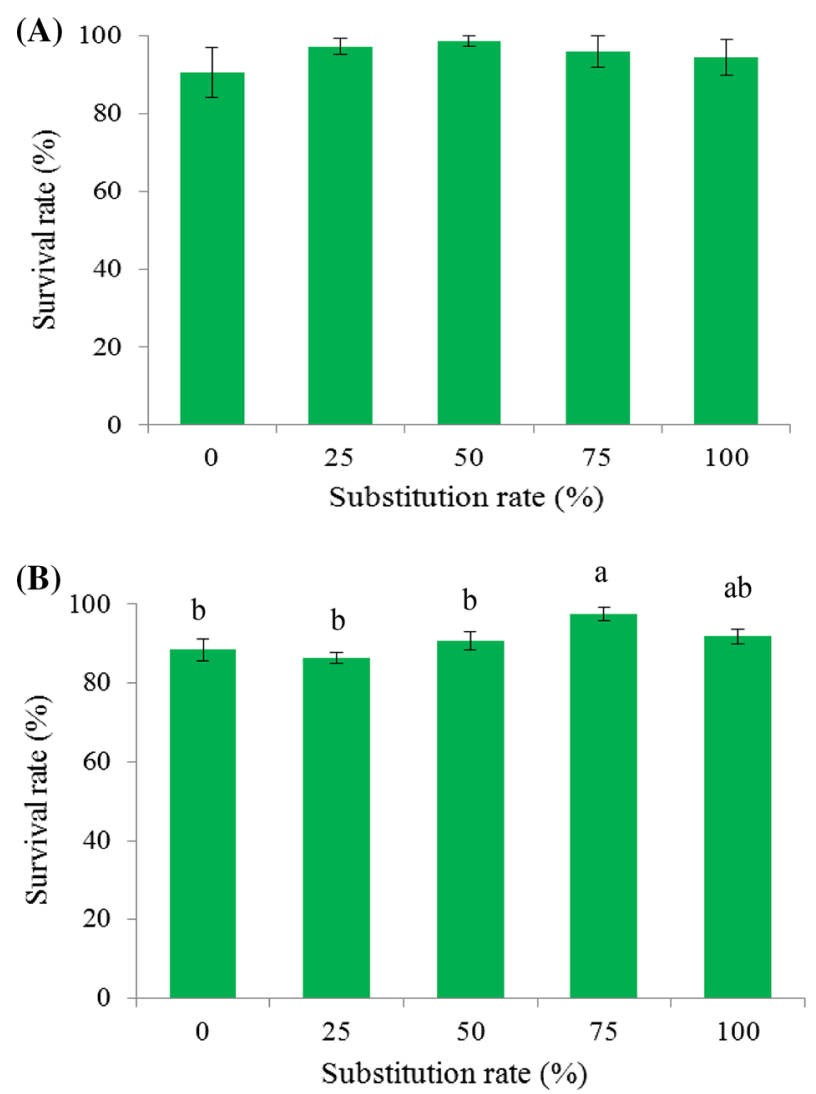

Fig. 5 Mean $( \pm \mathrm{SD})$ survival rate of hatchery-reared juvenile oysters fed on microalgae and different rations flocculated concentrates from shrimp pond water at the end of the 4 weeks experimental duration. Bars labeled with different letters are significantly different $(P<0.05)(\mathbf{A}=$ Experiment 1 and $\mathbf{B}=$ Experiment 2$)$

Robert 2002). Therefore, unsuitable storage methods may have negatively influenced the nutritional quality and directly affected the growth of juvenile oysters.

The gross chemical composition of food can be a defining factor when choosing diets as substitutes for microalgae in the nursery culture of bivalves in hatcheries. Therefore, preservation methods must be devised that keep the fatty acid content unchanged or that involve modifications that do not decrease the nutritional value of the biomass. In our study, the HUFA concentration in flocculated concentrates preserved in a refrigerator at $4{ }^{\circ} \mathrm{C}$ decreased to an undetectable level at 4 weeks of storage time. Degeneration of fatty acids in flocculated concentrates depends on the species of microalgae and storage techniques. For example, studies have found that concentrates of Isochrysis galbana stored at $4{ }^{\circ} \mathrm{C}$ with continuous illumination had fatty acids located in storage lipids which decreased over time while polyunsaturated fatty acids (EPA, DHA) remained unaltered (Grima et al. 1994), while spray-dried T. suecica can cause a loss by oxidation of highly unsaturated fatty acids (Robert et al. 2001). The poor performance reported by operators of dried microalgae was mostly associated with the difficulty of keeping cells in suspension without disintegrating them (Laing and Millican 1992). Types with a good nutritional value and the best shelf life include the C. calcitrans, S. costatum and Tetraselmis spp. concentrates prepared by centrifuge, whereas the flagellates $P$. lutheri and Isochrysis sp. are easily damaged and deteriorate rapidly (McCausland et al. 1999; Heasman et al. 2000). Preservation of flocculated concentrates from shrimp pond water in a refrigerator at $4{ }^{\circ} \mathrm{C}$ in this study has been shown to be an unsuitable method.

Assessment of flocculated concentrates from shrimp pond water as a supplementary diet for juvenile oysters

Flocculated concentrates of microalgae can be used effectively as supplementary diets in bivalve hatcheries. Substitution of microalgal concentrates for fresh microalgae have been used successfully as part of mixed or 
complete diets for larval or juvenile bivalves (Nell and O'Connor 1991; McCausland et al. 1999; Heasman et al. 2000; Knuckey et al. 2006). Flocculated concentrates from selected shrimp pond water contain a high proportion of microalgae, but are composed of different species. Previous studies have shown that 1-2 week old preparations of microalgal concentrates ( $C$. calcitrans and $S$. costatum) gave growth equivalent to live microalgae when presented as part of a mixed diet to juvenile Crassostrea gigas (McCausland et al. 1999) and in the same species, the use of the same concentrates for a longer period (4 weeks) gave significantly lower growth compared to corresponding diet of fresh microalgae (Ponis et al. 2003a). Those results and our findings in the preservation study indicate that flocculated concentrates produced from fresh microalgae and from intensive shrimp pond water used as a diet in this study could be kept in a refrigerator at $4{ }^{\circ} \mathrm{C}$ for a period of less than one week, a reasonable time, and maintain their nutritional value without effect on the growth of experimental oysters. From experiments, a partial substitution in the diet of $75 \%$ of flocculated concentrate from intensive shrimp pond water for microalgal concentrates produced higher growth in comparison with oysters fed on $100 \%$ microalgal concentrates in both experiments. In contrast, replacement with $100 \%$ flocculated concentrates from shrimp pond gave significantly lower growth compared to replacements of below $75 \%$ or the use of $100 \%$ microalgal concentrates. In this case, complete replacement probably causes nutritional deficiency because of an imbalance of nutrients. This finding is similar to the results of a study by Brown and Robert (2002), who demonstrated that flocculated concentrates of microalgae (Chaetoceros sp.) can be used effectively as major dietary components for juvenile oysters. In follow-up experiments, concentrates prepared from $C$. тиelleri cultures were effective as a supplementary diet and improved the growth of juvenile $C$. gigas and the scallop Pecten fumatus reared under commercial conditions, though not as effectively as corresponding live microalgae (Knuckey et al. 2006). In general, alternative diets have been tested as a partial replacement for fresh food, whereas bivalves are normally fed with a multispecies diet that allows a better balancing of essential compounds, with particular reference to polyunsaturated fatty acids (PUFAs), and assures high growth and survival (Enright et al. 1986; Laing and Millican 1986). Nevertheless, when used as a complete replacement for fresh microalgae, these diets generally do not adequately feed juveniles. The nutritional value of these concentrates and pastes of different microalgal species has been evaluated with juvenile oysters (Nell and O'Connor 1991; McCausland et al. 1999; Heasman et al. 2000; Robert et al. 2001) with some promising results. It has been shown that a mixed diet of two or more algal species provides a better balance of nutrients, because certain algae differ in their lipid (Brown et al. 2001) and highly unsaturated fatty acids (HUFAs) content (Renaud et al. 1999 and Leonardos and Lucas 2000). A similar result was found in this study, as the inclusion of the microalgal concentrates (C. calcitrans and T. suecica) component in a mixed diet may have compensated for any nutritional deficiency in the concentrates. The presence of HUFAs, specifically EPA (eicosapentaenoic acid), DHA (docosahexaenoic acid) and ARA (arachidonic acid) has been seen as an indication of high nutritional value (Knauer and Southgate 1999) that promotes good growth and a high survival rate in hatchery and nursery production of larval and juvenile oysters. The best diet for culturing European oyster juveniles was a mixture of microalgal diets which led to better growth rates and higher levels of PUFAs (Ronquillo et al. 2012). In addition, flocculated concentrates from shrimp pond water not only contain microalgae, but also clay minerals. This may enhance efficiency in ingestion and assimilation in oysters. Oysters live and grow in estuarine habitats characterized by high concentrations of suspended inorganic material. Several experiments have been carried out to determine how suspended clay particles affect the amount of food ingestion by the oysters $C$. virginica (Urban and Kirchman 1992) and C. gigas (Sornin et al. 1988) and the mussels Mytilus edulis (Bayne et al. 1987). Those studies concluded that a suitable threshold concentration of clay particle mixed in food facilitates ingestion and increases the time food remains in the intestine, leading to increase in the efficiency of absorption. The role of clay minerals in supporting growth has been reported in the oyster $C$. virginica (Nell and Jordan 1983). High protein content in flocculated concentrates used in experiment 2 might support growth performance in juvenile oysters in comparison with experiment 1.

Various studies have been carried out on the diet of different species of hatchery-reared bivalves in which 40-50\% of the microalgae diet has been successfully replaced by different types of cereal meals and macroalgae (Pérez Camacho et al. 1998; Albentosa et al. 1999, 2002; Tanyaros and Chuseingjaw 2014), Our findings indicate that substituting flocculated concentrates of shrimp pond water for $75 \%$ of microalgae led to better growth of juvenile oysters, but using flocculated concentrates as a mono-diet is unlikely to be suitable for feeding juvenile oysters. Further research is needed to find the best way to minimize problems with 
the use of flocculated concentrates, such as methods and storage time to best maintain the nutritional value and also to prevent clumping in the water. In addition, more research is needed on the toxicological effects of synthetic polymer flocculates for safe use in a bivalve hatchery.

Acknowledgments The authors thank Supatcha Chusiengjaw and Pacharee Kewprakan for sample collection. We also wish to thank William Martin for assistance in editing the manuscript. This study was funded by the Rajamangala University of Technology Srivijaya, annual budget year 2014.

Open Access This article is distributed under the terms of the Creative Commons Attribution 4.0 International License (http:// creativecommons.org/licenses/by/4.0/), which permits unrestricted use, distribution, and reproduction in any medium, provided you give appropriate credit to the original author(s) and the source, provide a link to the Creative Commons license, and indicate if changes were made.

\section{References}

Albentosa M, Fénandez-Reiriz MJ, Pérez Camacho A, Labarta U (1999) Grow performance and biochemical composition of Ruditapes decussatus spat fed on microalgal and wheatgerm flour diets. J Exp Mar Biol Ecol 232:23-37

Albentosa M, Pérez Camacho A, Fénandez-Reiriz MJ, Labarta U (2002) Wheatgerm flour in diets for Manila clam, Ruditapes philippinarum, spat. Aquaculture 212:335-345

Bayne BL, Hawkins AJS, Navarro E (1987) Feeding and digestion by the mussel Mytilus edulis L. (Bivalvia: Mollusca) in mixtures of silt and algal cells at low concentrations. J Exp Mar Biol Ecol 111:1-22

Brown M, Robert R (2002) Preparation and assessment of microalgal concentrates as feeds for larval and juvenile Pacific oyster (Crassostrea gigas). Aquaculture 207:289-309

Brown MR, Jeffrey SW, Garland CD (1989) Nutritional aspects of microalgae used in mariculture: a literature review. CSIRO Marine Laboratories Report 205

Brown MR, McCausland MA, Kowalski K (2001) The nutritional value of four Australian microalgal strains fed to Pacific oyster Crassostrea gigas spat. Aquaculture 165:281-293

Burford M (1997) Phytoplankton dynamics in shrimp ponds. Aquacult Res 28:351-360

Casé M, Leca EE, Leitão SN, Anna EES, Schwamborn R, de Moraes T Jr (2008) Plankton community as an indicator of water quality in tropical shrimp culture ponds. Mar Poll Bull 56:1343-1352

Coutteau P, Sorgeloos P (1992) The use of algal substitutes and the requirement for live algae in hatchery and nursery rearing of bivalve molluscs: an international survey. J Shellfish Res 11:467-476

Enright CT, Newkirk GF, Craigie JS, Castell JD (1986) Growth of juvenile Ostrea edulis L. fed Chaetoceros gracilis Schutt of varied chemical composition. J Exp Mar Biol Ecol 96:15-26

Folch AJ, Less M, Sloan-Stanley GH (1957) A simple method for isolation and purification of total lipids from animal tissues. J Biol Chem 226:497-509

Funge-Smith SJ, Briggs MRP (1998) Nutrient budgets in intensive shrimp ponds: implications for sustainability. Aquaculture 164:117-133

Grima EM, Sánchez Peŕez JA, García Camacho F, Acién Femández FG, López Alonso D, Segura del Castillo CI (1994) Preservation of the marine microalga Isochrysis galbana; influence on the fatty acid profile. Aquaculture 123:377-385

Heasman MP, Diemar J, O'Connor W, Sushames T, Foulkes L (2000) Development of extended shelf-life microalgae concentrate diets harvested by centrifugation for bivalve molluscs: a summary. Aquacult Res 31:637-659

Helm MM, Bourne N, Lovatelli A (2004) Hatchery culture of bivalves: a practical manual. FAO Fisheries Technical Paper No. 471. Food and Agriculture Organization of the United Nations Publishing, Rome, Italy

Islam S, Sarker J, Yamamoto T, Wahab A, Tanaka M (2004) Water and sediment quality, partial mass budget and effluent N loading in coastal brackish water shrimp farms in Bangladesh. Mar Poll Bull 48:471-485

Jacob GS, Pruder GD, Wang JK (1993) Growth trial with the American oyster Crassostrea virginica using shrimp pond water as feed. J World Aquacult Soc 24:344-554

Jones AB, Preston NG (1999) Sydney rock oyster, Saccostrea commercialis (Iredale \& Roughley), filtration on shrimp farm effluent: the effects on water quality. Aquacult Res 30:51-57

Jones AB, Dennison WC, Preston NP (2001) Integrated treatment of shrimp effluent by sedimentation, oyster filtration and macroalgal absorption: a laboratory scale study. Aquaculture 193:155-178

Knauer J, Southgate PC (1999) A review of the nutritional requirements of bivalves and the development of alternative and artificial diets for bivalve aquaculture. Rev Fish Sci 7:241-280

Knuckey MR, Brown MR, Robert R, Frampton DMF (2006) Production of microalgal concentrates by flocculation and their assessment as aquaculture feeds. Aquacult Eng 35:300-313

Laing I, Millican PF (1986) Relative growth and growth efficiency of Ostrea edulis L. spat fed various algal diets. Aquaculture $54: 245-262$

Laing M, Millican PF (1992) Indoor nursery cultivation of juvenile bivalve molluscs using diets of dried algae. Aquaculture 102:231-243

Leonardos N, Lucas IAN (2000) The nutritional value of algae grown under different culture conditions for Mytilus edulis L. larvae. Aquaculture 182:301-315 
Lertsutthiwong P, Sutti S, Powtongsook S (2009) Optimization of chitosan flocculation for phytoplankton removal in shrimp culture ponds. Aquacult Eng 41:188-193

Lorenzen CJ (1967) Determination of chlorophyll and pheopigments: spectrophotometric equations. Limnol Oceano 12:343-346

Manzi JJ, Rourke CB, Bobo MY, Steele GH, Smiley RA (1988) Result of an oyster-shrimp pond biculture study. J Shellfish Res 7:205-206

McCausland MA, Brown MR, Barrett SM, Diemar JA, Heasman MP (1999) Evaluation of live microalgae and microalgal pastes as supplementary food for juvenile Pacific oysters (Crassostrea gigas). Aquaculture 174:323-342

Nell RIE, Jordan SJ (1983) Preferential ingestion of organic material by the American oyster Crassostrea virginica. Mar Ecol Prog Ser 13:81-A

Nell JA, O'Connor WA (1991) The evaluation of fresh algae and stored algal concentrates as a food source for Sydney rock oyster, Saccostrea commercialis (Iredale and Roughley). Aquaculture 99:277-284

Nunes M, Pereira A, Ferreira JF, Yasumaru F (2009) Evaluation of the microalgae paste viability produced in a mollusk hatchery in southern Brazil. J World Aquacult Soc 40:87-94

Pérez Camacho A, Albentosa M, Fernández-Reiriz MJ, Labarta U (1998) Effect of microalgal and inert (cornmeal and cornstarch) diets on growth performance and biochemical composition of Ruditapes decussatus seed. Aquaculture 160:89-102

Ponis E, Robert R, Parisi G (2003a) Nutritional value of fresh and concentrated algal diets for larval and juvenile Pacific oysters (Crassostrea gigas). Aquaculture 221:491-505

Ponis E, Robert R, Parisi G, Tredici M (2003b) Assessment of the performance of Pacific oyster (Crassostrea gigas) larvae fed with fresh and preserved Pavlova lutheri concentrates. Aquacult Inter 11:69-79

Ponis E, Parisi G, Chini Zittelli G, Lavista F, Robert R, Tredici MR (2008) Pavlova lutheri: production, preservation and use as food for Crassostrea gigas larvae. Aquaculture 282:97-103

Renaud SM, Thinh LV, Parry DL (1999) The gross chemical composition and fatty acid composition of 18 species of tropical Australian microalgae for possible use in mariculture. Aquaculture 170:147-159

Reynolds CS (2006) The ecology of phytoplankton. Cambridge University Press, New York

Robert R, Parisi G, Rodolfi L, Poli BM, Tredici MR (2001) Use of fresh and preserved Tetraselmis suecica for feeding Crassostrea gigas larvae. Aquaculture 192:333-346

Rodriguez RA, Paez-Osuna F (2003) Nutrients, phytoplankton and harmful algal blooms in shrimp ponds: a review with special reference to the situation in the Gulf of California. Aquaculture 219:317-336

Ronquillo JD, Fraser J, McConkey A-J (2012) Effect of mixed microalgal diets on growth and polyunsaturated fatty acid profile of European oyster (Ostrea edulis) juveniles. Aquaculture 360-361:64-68

Sandifer PA, Hopkins JS (1996) Conceptual design of a sustainable pond-based shrimp culture system. Aquacult Eng 15:41-52

Shaari AL, Surif M, Latiff FA, Omar WMW, Ahmad MN (2011) Monitoring of water quality and microalgae species composition of Penaeus monodon ponds in Pulau Pinang, Malaysia. Trop Life Sci Res 2011:51-69

Sornin J, Deslouspaoli J, Hesse O (1988) Experimental study of the filtration of clays by the oyster Crassostrea gigas (Thunberg): adjustment of particle size for best retention. Aquaculture 69:355-366

Tanyaros S (2000) Use of the oyster Crassostrea belcheri (Sowerby) as a biofilter in intensive shrimp pond water. Dissertation. Asian Institute of Technology. Bangkok, Thailand

Tanyaros S, Chuseingjaw S (2014) A partial substitution of microalgae with single cell detritus produced from seaweed (Porphyra haitanensis) for the nursery culture of tropical oyster (Crassostrea belcheri). Aquacult Res 2014:1-9. doi:10.1111/are.12662

Tanyaros S, Tarangkoon W (2014) Water quality, growth and mortality of tropical oyster Crassostrea belcheri spat in the conserved natural oyster beds of Trang province, southern Thailand. In: 2nd International Conference on Fisheries Science. 30-31 July, 2014. Colombo, Sri Lanka, pp 55-59

Tanyaros S, Choopunth P, Kurokura H (2002) A basic design and operating for shrimp-settling-oyster integration system to reduce discharge problem. Fish Sci 68:843-846

Tanyaros S, Pattanatong T, Tarangkoon W (2012) Effect of water flow rate and density on nursing hatchery-reared juvenile oysters, Crassostrea belcheri (Sowerby 1871) in a semi-closed recirculation system. J Appl Aqua 24:364-373

The Association of Official Analytical Chemists (2012) Official methods of analysis of AOAC international, 19th edn, Virginia. AOAC 2001.11: 2012

Tookwinas S, Songsangjinda P (1999) Water quality and phytoplankton communities in intensive shrimp culture ponds in Kung Krabaen Bay, eastern Thailand. J World Aquacult Soc 30:36-45

Tzovenis I, Triantaphyllidis G, Naihong X, Chatzinikolaou E, Papadopoulou K, Xouri G, Tafas T (2004) Cryopreservation of marine microalgae and potential toxicity of cryoprotectants to the primary steps of the aquacultural food chain. Aquaculture 230:457-473

Urban ER Jr, Kirchman DL (1992) Effect of kaolinite clay on the feeding activity of the eastern oyster Crassostrea virginica (Gmelin). J Exp Mar Biol Ecol 160:47-60

Van Wijngaarden D (1967) Modified rapid preparation of fatty acids esters from lipids for gas chromatographic analysis. Anal Chem 39:848-849

Walne PR (1974) Culture of bivalve molluscs: 50 years' experience at Conwy. Fishing News (Books) Ltd, West Byfleet

Yusoff FM, Zubaidah MS, Matias HB, Kwan TS (2002) Phytoplankton succession in intensive marine shrimp culture ponds treated with a commercial bacterial product. Aquacult Res 33:269-278

Zhukova NV, Aizdaicher NA (1995) Fatty acid composition of 15 species of marine microalgae. Phytochem 39:351-356 